\title{
Interaction of arrangements of the local spatial management plan in the field of environmental protection with the investment and construction process
}

\author{
Edward Preweda ${ }^{1, *}$ \\ ${ }^{1}$ AGH University of Science and Technology, Poland
}

\begin{abstract}
The local spatial management plan, adopted in Poland at the level of the municipality, is a source of universally binding law, determines the purpose of the area, the distribution of public purpose investments and defines the ways of development and the conditions for land development. The local plan is the basis for issuing the building permit decision on the areas for which its arrangements apply. It directly interferes with the rights vested in entities in real property and property rights. The provisions of the plan, as an act of universally binding law, bind everyone, including all administrative bodies and courts, as well as property owners. When adopting a local spatial management plan, the commune council should be guided by a number of values, including maintaining spatial order, architectural and landscape values, as well as environmental protection requirements. A local plan is an act of local law, therefore it must contain standards defining the specific purpose of each area covered by the regulation in an unambiguous manner, it cannot contain provisions that make land development conditional on subsequent opinions of public administration authorities or allow any entities to individually agree on deviations from the adopted plan. In practice, however, the ambiguity of provisions regarding environmental protection is noticed, in particular in the interpretation of the concept of biologically active land. The work presents how significantly this problem affects the construction investment.
\end{abstract}

\section{Introduction}

In the opinion of many experts, the system that regulates the investment process in Poland is complicated, ambiguous, cumbersome to use and, consequently, expensive. Constantly changing legal acts, containing many inconsistent provisions, do not allow to establish a clear path to obtain documents required before the start of construction works, meeting all the necessary conditions for its subsequent implementation. First and foremost, it is necessary to introduce a coherent language that is used by legal acts. In this respect, one of the most important regulations and harmonization that should be carried out in Poland is the need to improve environmental procedures, the aim of which should be to eliminate investments that may actually harm the environment already at the stage of building permit or construction notification. Particular problems are notifications in provisions that contain definitions of terms used in legal acts, which results in a series of interpretations, sometimes diametrically opposed. Some of the concepts used in the regulations do not have any legal definitions, so-called legal definitions. An equally serious issue is the inconsistency of the definitions of urban and architectural concepts contained in individual acts of law.

\footnotetext{
* Corresponding author: preweda@agh.edu.pl
}

\section{Investment Location And Local Social Conflicts}

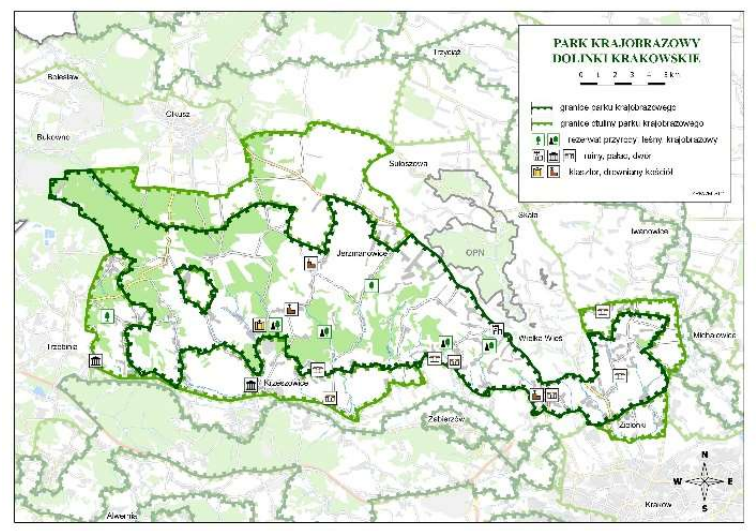

Fig. 1. The borders of the Krakow Dolinki landscape park. Source: Spatial Information System, Zielonka Commune, 2018.

The investment under the name "Construction of six single-family semi-detached houses with two premises each (3 AC twins), ... with installations with external ..., construction of an internal road, parking spaces, rainwater drainage and a rainproof tank on a construction plot from the registration plots No. 532/1, 532/2, 532/3, 532/4, 
$532 / 5$ and construction of the exit .. "is located in the town of Bibice, the commune of Zielonki, and the poviat of Kraków. The investment area is located in the area of the Dolinki Krakowskie landscape park (Fig. 1) [7].

The Local Spatial Plan (Figure 2) applies to the area foreseen by the investment [6]. According to this plan, this area is intended for single-family housing. In the neighborhood there is loose single-family housing (Fig. $3)$.

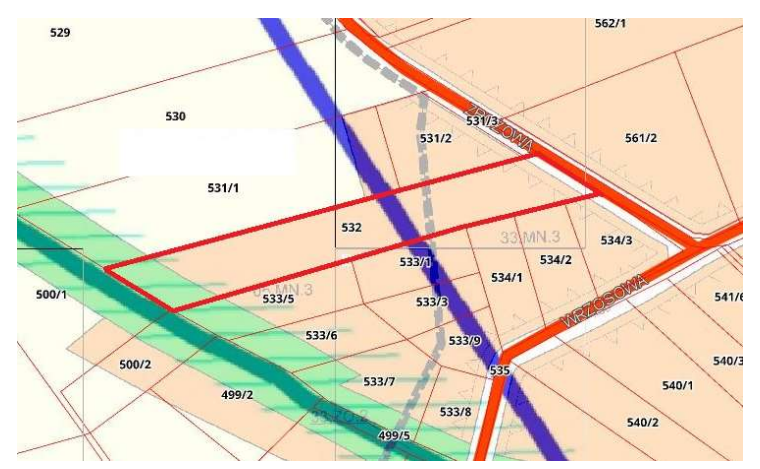

Fig. 2. A fragment of the Local Development Plan for the investment area. Source: Zielonki Commune Office.

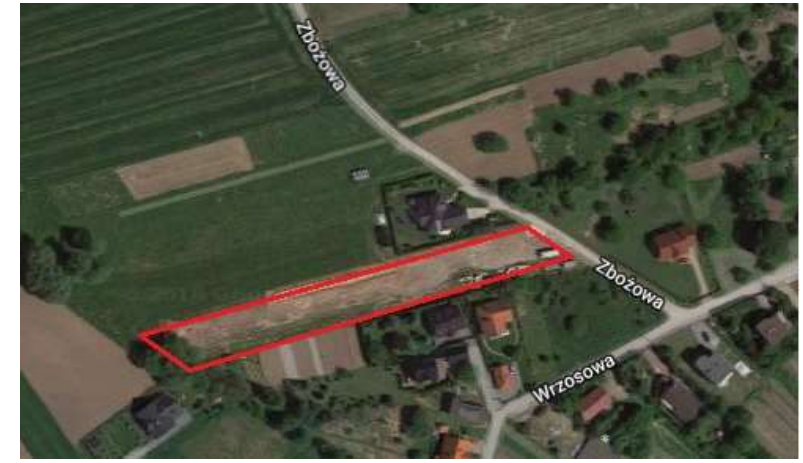

Fig. 3. Buildings in the vicinity of the investment location.

At the subject property, which was previously divided into 5 plots of land $[1,2]$, the developer designed in the first version 8 , and when he did not obtain the permission of the building permit, " 6 single-family houses ... with two premises each" (Fig. 4). Because the building plot is adjacent only with a short side to the road, an internal road was designed, later called a walking walk. As a result, almost the entire plot has been planned to be built, whereas the local plan requires that a minimum of $60 \%$ of the area of the record plot be biologically active.

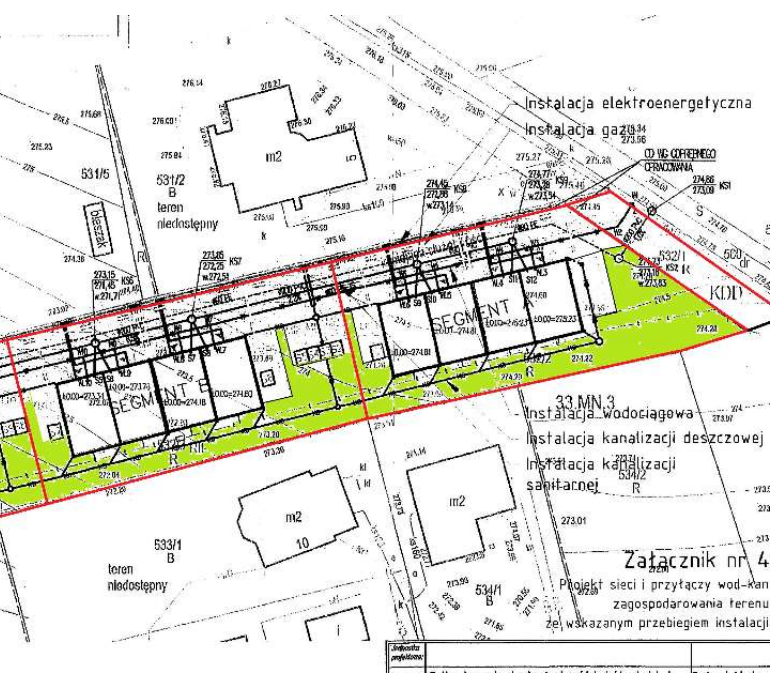

The developer managed the identical buildings earlier in the Zielonki commune, but in the areas designated for multi-family housing. According to the designer, two single-family houses have the form as in Fig. 5.

The proposed investment aroused opposition of local residents, who expressed the opinion that the developer's action is unpardonious and contrary to the Local Spatial Development Plan [6]. In the middle of the land intended for single-family housing and genuinely inhabited, a multi-family housing estate was designed (under the pretext of single-family houses), unsuited to the needs of the housing estate or to the surroundings, with complete lack of respect for the residents' neighbouring properties. Particular attention was paid to the shocking fact that in the case of construction of a similar investment, the developer used unlawful practices, consisting in showing the built-up area as a biologically active area (Fig. 6 and Fig. 7).
Fig. 5. Two "single-family houses" - according to the designer. 


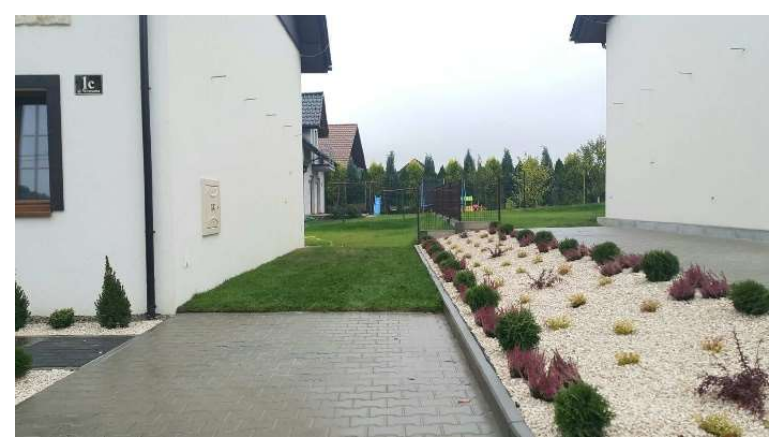

Fig. 6. „Biologically active area” before receiving the object. Source: own study.

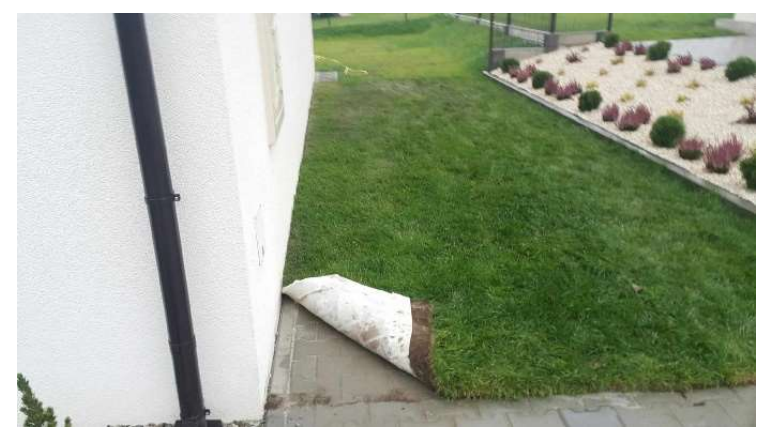

Fig. 7. Removed artificial surface - paving stones and parking space after receiving the object. Source: own study.

\section{Appeals against building permit decisions}

Participants in the proceedings (neighbours) expressed their opinions in the Poviat Eldership and written objections together with the justification at the stage of issuing the building permit decisions by the Starost of Krakow, which, however, issued the decision. From the decision of the Starost of Krakow from 15.12.2016 approving the construction design and granting permission for the construction of the investment entitled: "Construction of six single-family residential buildings with two premises each (3 A-C twins) ..." appealed to the Governor of Małopolska, accusing what earlier. The voivode maintained the contested decision in force.

The above decisions were made in the following factual and legal state: Under the decision of the Starost of Cracow, pursuant to art. 28, art. 33 para. 1, art. 34 par. 4, art. 36 of the Building Law Act, granted the Investor permission to build the investment described above. The decision was made by the Voivode of Małopolska with the owners of plots neighbouring the investment area from the north and south. The appellants alleged a gross violation of the law due to non-compliance with the current local plan, including through incorrect interpretation of the biologically active terrain, development in a serial arrangement, designing an internal road not included in the plan. In the opinion of the appeal body, the analysis of all the collected evidence did not confirm the accuracy of the allegations of appeal.
Owners of plots neighbouring the investment site finally filed a complaint against the decision of the Małopolska Province Governor dated 24 March 2017 to the Provincial Administrative Court in Krakow.

\section{Complaint about the voivode's decision to the Provincial Administrative Court}

Complaint against the decision of the Governor of Malopolska of 24 March 2017, confirming the decision of the Starost of Krakow of 15 December 2016 approving the construction design and granting permission for the construction of the investment named: "Construction of six single-family residential buildings .." was brought to the Provincial Court Administrative Court in Krakow based on art. $3 \S 2$ point 1 p.s.a. in conjunction from art. $50 \S 1$ p.s.a. and art. 51 p.s.a. The applicants appealed against the decision of the Governor in their entirety, alleging violation of the substantive law through erroneous interpretation - incorrect interpretation of the content and meaning of the provisions contained in the Local Spatial Development Plan of the municipality of Zielonki No. 33 in the area of Bibice near Pod Lasem, approved by Resolution No. XXXI/112/2005 of the Commune Council of Zielonki on November 18, 2005 and the Local Spatial Development Plan of the Zielonka Commune No. 05 in the area of Bibice, approved by Resolution No. XXXI/127/2005 of the Zielonki Commune Council of December 20, 2005, published in the Official Journal of the Małopolska Region, hereinafter referred to as the complaint as SPDP. At the same time, they requested that the contested decision and the decision of the first instance authority be removed in full because of the violation which had a significant impact on the outcome of the proceedings and award the plaintiffs the reimbursement of the costs according to the prescribed norms.

\subsection{Justification of the complaint}

By decision of 24 March 2017, the Province Governor of Malopolska maintained the decision of the Starost of Krakow (No. AB.III-W.1.1374.2016) appealed on 12 January 2017. Apart from the deadline for reviewing the appeal, the justification of the decision violates the substantive law through incorrect interpretation - an erroneous interpretation of the content and meaning of the provisions of the LSDP.

Violation of substantive law:

There is no legal area for biologically active areas planned for development under development, interpreting the investment area contrary to the definition given in the local spatial development plan for the area covered by the investment. The Local Development Plan clearly defines the concept of the biologically active area and the investment area, referring it to the register plot.

Pursuant to $\S 8$ para. 1 LSDP:

Whenever the resolution refers to:

14) "register plot" - it should be understood as a plot within the meaning of separate regulations; 
19) "biologically active area indicator" - it should be understood as a parameter, expressed as a percentage share of the land surface, which cannot be built on a surface or volume (also deep into the ground) within the investment area. The percentage calculation of the proportion of biologically active area includes $50 \%$ of the sum of the surface of terraces and flat roofs with an area of not less than $10 \mathrm{~m}^{2}$ arranged as permanent lawns or flowerbeds on the ground providing them with natural vegetation;

23) "investment area" - it should be understood as the area covered by the design of a parcel of land under which the cubage object is located;

Pursuant to $\S 15$ para. 4 point 4 LSDP:

The following are determined as land development rules and building conditions:

4) a special obligation to maintain a minimum of $60 \%$ of the investment area area as biologically active;

The definition of a parcel of land is given in the Notice of the Minister of Administration and Digitization of February 27, 2015 regarding the publication of a uniform text of the Ordinance of the Minister of Regional Development and Construction regarding the registration of land and buildings, Dz. U. Pos. 542 of 17 April 2015: $\S 9$. 1. The cadastral plot is a continuous area of land, located within one area, homogeneous in legal terms, separated from the surroundings by means of boundary lines.

2. The neighbouring parcels, which are subject to the same rights and the possession of the same persons or organizational units, are listed in the register as separate parcels, if:

1) were separated as a result of the division of real estate, and materials created as a result of geodetic and cartographic work related to this division were adopted to the state geodetic and cartographic resource;

2) are specified in existing documents defining the legal status of real estate, in particular in land and mortgage registers, document collections, notarial deeds, final court decisions and final administrative decisions, and at the same time are plots of land or building plots within the meaning of the Act of August 21, 1997 about real estate management;

The designed investment includes 5 registered plots. In accordance with the above-quoted regulations resulting from the Regulation and the provisions in the Local Plan of Action, a minimum of $60 \%$ of the biologically active area must be maintained on every registered parcel. There are known judgments of the Supreme Administrative Court regarding the recognition of several plots of land for investment. However, this applies to cases in which there were no local spatial development plans or these plans did not clearly define the concept of investment area. In this case, the LSDP definition clearly defines the concept of investment area, it is probably well thought out and purposeful, because it is associated with the Zielonka Commune Strategy, which as weaknesses in the SWOT analysis gives, inter alia, the lack of the Commune's influence on developers' activities.

Violation of substantive law:

The planned investment is a terraced development, forbidden by the relevant local spatial development plan.
Pursuant to $\S 11$ para. 1 point 8 LSZP: The following areas are prohibited in the areas included in the plan:

8) location of buildings in a serial configuration, with the exception of areas for which this type of building has been defined as a basic purpose.

The serial system is not permissible, in accordance with the valid Local Spatial Development Plan of the Zielonki Commune no. 33 in the area of Bibice near the Forest, except for areas specially designated for this purpose. It should be noted that the serial system is not identical with the serial building. In this case, a serial system is designed.

Violation of substantive law:

The designed internal road is not included in the Local Development Plan.

Pursuant to $\S 6$ para. 1 point 3 d) MPZP internal roads are marked on the plan drawing with the symbol KDW. Pursuant to $\S 3$ para. 1 MPZP, we complain that the intended project does not comply with the investment compliance with $\S 3$ para. 2 point $1, \S 3$ para. 2 point $3, \S$ 3 para. 2 point $4, \S 3$ para. 2 point $5, \S 3$ para. 2 point 8 . The $\S 3$ para. 3 Local Plan

It was also claimed that the area of impact of the planned construction objects significantly and adversely affects neighbouring plots, will cause nuisance and lowering the neighbourhood standard. It is the stopping of light and air, smells and impurities resulting from the collection of solid waste, noise. These are only examples of indirect immunities that disrupt the use of neighbouring properties $[3,5]$. In particular, the nuisance and lowering of the neighbourhood standard will result from the excessive density of the designed buildings (4 families on one land plot with an area of about 10 areas in the area intended for single-family housing) and de facto multi-family buildings under the pretext that it is single-family housing.

\subsection{Judgment of the Provincial Administrative Court}

The Provincial Administrative Court in Krakow after hearing on 26 October 2017 the case of the complaint against the decision of the Voivod of Małopolska regarding the approval of the construction design and granting the building permit overturned the contested decision and the previous decision of the first instance authority and ordered the applicant to pay the costs of the proceedings.

First, the Court, explaining the further motives of the judgment, indicated that, in accordance with the provisions of $1 \S 2$ of the Act of 25 July 2002. Law on the administrative court system (Journal of Laws of 2016, item 1066) [8], judicial and administrative control shall be exercised within the scope of compliance with the law, unless the Act provides otherwise. The scope of public administration control also includes examining complaints regarding administrative decisions (Article 3 (2) (1) of the Act of 30 August 2002 Law on proceedings before administrative courts, Journal of Laws of 2016, Item 718 , as amended) ). hereinafter referred to as "ppsa") 
According to art. $145 \S 1$ p.p.s.a. The court, having regard to a complaint against a decision or provision, repeals a decision or provision in whole or in part if it finds: a violation of substantive law that affected the outcome of the case, an error of law giving grounds for resumption of administrative proceedings or other violation of the proceedings, if it could have significant impact on the outcome of the case. In addition, the court shall annul the decision or order in whole or in part, if the reasons set out in Art. 156 of the Code of Administrative Procedure or in other regulations, or states the issuance of a decision or provision in violation of the law, if there are reasons specified in the Code of Administrative Procedure or other regulations. If the complaint is dismissed in whole or in part, the court dismisses the complaint in whole or in part (Article 151, p.p.s.a.).

The subject of control by the Court, in the light of such specified criteria for legality testing, is the decision of the Governor, which this authority upheld the decision of the Starost of Krakow approving the construction project and granting permission for the construction of six singlefamily semi-detached houses with two premises each (3 A-C twins),,...” Analyzing the documents collected in the case, the Court found that there was doubt as to whether the construction project submitted by the investor met all the requirements necessary to obtain a building permit. Thus, the assessment in the present case covered whether the contested decisions were made pursuant to art. 35 ust. 1 and art. 32 para. 4 of the Construction Law.

The court pointed out that pursuant to art. 32 para. 4 of the Construction Law, a building permit may be issued only to the person who submitted the application in this case within the validity period of the decision on the land development and development conditions, if it is required in accordance with the planning and spatial development regulations and submitted a statement under pain of liability penal, having the right to dispose of the property for construction purposes. It is also necessary to notice that from the provision of art. 35 ust. 1 of the Construction Law states that prior to issuing the building permit, the architectural and construction body first checks the compliance of the construction design with the local spatial development plan or the decision on the land development and development conditions in the absence of a local plan, and environmental protection requirements, compliance of the developed project with a plot or area with regulations, including technical and constructional ones, and completeness of the construction project.

In the opinion of the court, the analysis of the files shows that the complaint had to have the intended effect, although not all of its allegations regarding the lack of compliance of the construction design with the provisions of the spatial development plan in force, the Court found accurate.

First and foremost, the Court noted, as part of the review of the legality of the decision appealed ex officio, that the land development map attached to the project does not fit its descriptive part because the boundaries of the adjacent adjoining parcels included in the investment are clearly marked; it is in fact marking the boundaries of the development and the entire investment area, or as specified in the decision of the building plot consisting of plots no. 531/1, 532/2, 532/3,532/4 and 532/5. Only the descriptive part of the land development project really shows that the investment plot is made up of plots with the "No. 532/1 - 532/5." This circumstance has escaped the attention of the bodies checking the compliance of the project with applicable law, in particular with $\S 8$ Paragraph 3 point 2 of the Ordinance of the Minister of Infrastructure of 3 July 2003 on the detailed scope and form of a construction design (Journal of Laws No. 120, item 1133, as amended) This failure in itself constitutes a sufficient basis for the annulment of the contested decisions due to the violation of the provisions of the proceedings, in particular Articles 7 and $77 \S 1$ of the Administrative Code.

Referring to the complaints of the complaint, the Court first discussed those of them that did not meet with the approval of the Court. The investment area, which includes five registered plots, is located within the area of two spatial development plans taken by the Zielonka Commune Council. The area marked with the symbol MN in both plans is single-family housing, for which the indicator of land development up to $40 \%$ and a special obligation to maintain a minimum of $60 \%$ of the area of the investment area as biologically active. The area marked with the ZO symbol is an unmanaged green area. In both acts, there were homogeneous provisions concerning, inter alia, definition of: "investment area" by which one should understand the area covered by the development project of the parcel of land on which the building is located ( $\S 8$ section 1 point $20, \S 8$ section 1 item 23 of the above-mentioned LSDP); "area" should be understood as an impassable parameter for the use of land with a fixed purpose and development principles, expressed as a percentage share of the area that can be used for development. In turn, the "indicator of biologically active area" should be understood as the parameter expressed as a percentage share of land surface, which cannot be surface or cubic (also deep into the ground) within the investment area, and finally "land plot" should be understood as land property or a plot of land whose size, geometrical features, access to a public road and equipment in technical infrastructure meet the requirements of construction works resulting from separate provisions and local law acts.

It is a fact that the resolutions of the Commune Council in its content are not precise because in the definition of the investment area it refers to the "limits of the plot development project", while in the case of the building indicator to the mathematical formula for calculating this parameter, it is assumed, among others: total area of the investment plot or area ". Finally, the building plot is a plot of land or a plot of land. The doubts arising in this connection should be interpreted in such a way that if the legislator distinguishes between the total area of one plot and the total area of the investment, this does not exclude the possibility that the investment plot may be created by several parcels included in the investment. Such an interpretation is also confirmed by the term "building plot" through which the legislator understands land property or plot of land, but these concepts are not equivalent. 
Colloquially, the ground property is simply a ground, a piece of land that is owned by someone else. In legal terms, the land is taken with the constituent parts, if it can constitute an independent subject of legal transactions (Article 46 of the Civil Code). The criterion for distinguishing a property also includes the land and mortgage register criterion, accepting that a real estate in the meaning of a land and mortgage register is a part of the land surface covered by one land and mortgage register "(Supreme Court decision of April 11, 2013, CSK 471/2012, LexisNexis No. 5168716, OSNC 2013, no. 12, item 145) If we combine several plots of land in one land and mortgage register, we can no longer talk about separate real estate properties: Combined plots in one land and mortgage register become one real estate property, it is also worth mentioning the definition of a plot of land located in the Land Management Act Article 4 point 3, according to which it should be understood as the undivided, continuous part of the earth's surface constituting a part or the whole of the land property.

A real estate can therefore consist of one or several plots of land. In the present case, all investment plots are covered by one land and mortgage register no. KR1P / 00225645/1 (see: K 58 adm. Act) The term "building plot" used in the decision of the authority of first instance in relation to the registration plots No. 531/1, 532 / 2, 532/3, $532 / 4$ and $532 / 5$ are in line with the provisions of the plans and are also synonymous with the concept of the investment site.

The court considered that the allegation of the complaint assessed as legitimate is the allegation of incompatibility of the proposed development with the provisions of spatial management plans to the extent that they prohibit "location of buildings in a row, except for areas for which this type of development was defined as a basic purpose" ( $\S 11$ par.1 point 8 in both files). The parcels belonging to the investment are mainly located in areas marked on the drawing with the symbol "MN" and for these areas as a basic purpose a single-family housing function has been established covering the existing and new buildings ( $\$ 15$ paragraph 2 and $\S 17$ section 2 ). The case raises no doubt that, according to the provisions of the Zielonki commune council, the investment area is intended for single-family housing, however, excluding the development in a serial system, the dispute boils down to answering the question whether the project approved by the authority In fact, the building construction is predicted in such a layout. In the Court's opinion, first of all, it should be emphasized that the legal provisions in force, as at the date of the contested decision, included in the Act of 7 July 1994 Construction Law (Journal of Laws of 2010 No. 243, item 1623, as amended), in the regulations issued on its basis and in local spatial development plans for the Commune of Zielonki, they do not define the legal definition of "terraced buildings" or "building in a serial system". The Court accepts that these two concepts are synonymous. It is therefore justified to pay attention to the provision of art. 3 point $2 \mathrm{a}$ of the Construction Law. According to this provision, whenever the Act refers to a single-family residential building - it should be understood as a detached building or a semidetached, terraced or group building serving for housing needs, constituting a constructionally independent unit in which no more than two dwellings or one dwelling and business premises with a total area not exceeding $30 \%$ of the total area of the building. The term "terraced buildings" undoubtedly means that a single-family residential building in terraced houses should constitute a constructionally independent whole, with a separate maximum of two premises. In the absence of a legal statutory definition and regulations from which it would be possible to interpret in a comprehensive manner the characteristics of the discussed type of building, it is also reasonable to reach to colloquial meaning indicating that terraced houses are a series of buildings adjacent to each other. According to the Universal Dictionary of the Polish language, edited by Stanisław Dubisz (PWN Warszawa 2008) under the term "serial", for example, houses arranged in series, it should be understood to form a series that are next to each other in one straight line. Having the above considerations in mind, it should be stated that terraced houses are created by a series of buildings, each of which is a constructionally independent unit from the technical and construction point of view. Also, the courtadministrative case law confirms that this type of building is created by setting in a series of building segments, noting that in this way it combines the features of a collective and individual residence, and allows for intensive use of built-up areas (see the judgment of the Supreme Administrative Court of October 27, 2009, judgment on the website www.orzeczenia.nsa.gov.pl). In the context of the above, it is permissible to state that single-family terraced houses are made of three to a dozen or so buildings. Due to the construction project submitted, which is the subject of single-family semi-detached houses, it is necessary to explain the concept of "semidetached buildings", for which there is also no legal definition. the building has separate external walls so that each of the buildings can be a separate object of property .The Supreme Administrative Court in the judgment of 21/10/2016 in the case No. OSK 64/15 indicated that "if there is a gap dilatation is not an element necessary to recognize that the building is a "twin", undoubtedly for such a statement it is necessary to have two separate walls, for example adjacent to each other. In other words: a semidetached house is actually two separate buildings adjoining one another from the walls (yes also $m$ in the judgment of 29 June 2012 file reference No. OSK 612/11, available at http://:orzeczenia.nsa.gov.pl). "Following this line of reasoning, in the Court's opinion, it is legitimate to say that single-family semi-detached houses consist of two segments adjacent to one another, and in each of these segments, no more than two dwellings or one apartment and business premises.

Referring the above to the construction project subject to control in the present case, in the opinion of the Court, it does not meet the conditions laid down for single-family semi-detached housing. Recalling the subject of the project as "building single-family semi-detached houses with two dwellings (3 AC twins) (...)" it should be noted that the land development project shows that each "twin" consists of a total of four buildings (two twin segments separated only by a dilatation wall, and in each segment there are two buildings adjoining one of the walls). Each 
building has separate external walls, and the facade design also shows that each of these buildings has a separate entrance. The concept of a single-family residential building refers to a building constituting a constructionally independent whole, and it is only within its framework that two dwellings or one dwelling and commercial premises can be separated.

In the opinion of the Court, the above circumstances determine the erroneous assessment of the bodies that have recognized without thinking that in the presented project we are dealing with twin buildings. This in turn must lead to the conclusion that if we are not dealing with twin buildings, then the design of building three buildings, consisting of four buildings (constituting an independent technical-constructional whole), is in fact buildings in a series system, and this the type of development is in turn excluded within the areas marked in the current spatial development plans with the symbol "MN".

In view of the above, the Court found that the alleged deficiencies in the violation of the rules of conduct resulted in a breach of substantive law in the scope of $\S 8$ section 3 point 2 of the Regulation of the Minister of Infrastructure of 3 July 2003 regarding the detailed scope and form of the construction design, art. 3 point $2 \mathrm{a}$ of the Construction Law and the provisions of local spatial development plans adopted on 18.11.2005 and on 20.12.2005 within the scope of $\S 11.1$ of this Act. This in turn determined the necessity to set aside the appealed decisions, what the Court ruled in the judgment on the basis of art. $145 \S 1$ point 1 lit. a and c p.p.s.a.

\section{Conclusions}

Investment law provisions use imprecisely defined planning, architectural or construction concepts. This situation causes many complications, first of all in the form of difficult to predict administrative decisions [4]. Particular definitions of notions that are even thematically similar, are contained in separate acts of law and are not always consistent with each other. Scattering the definition makes it difficult for designers, officials, investors and all parties to the proceedings. The analysis of examples of the effects of the provisions leads to the conclusion that legislative work is needed to unify the language of concepts used in the investment process. Most problems are caused by situations in which the same terms for different content appear, either the same or similar concepts have different definitions. One of the examples of concepts interpreted differently are "biologically active area", "biologically active area", "investment area", "serial building", "serial layout". Different interpretations of these definitions have become the source of far-reaching misunderstandings and, ultimately, the suspension of the investment process. It should be mentioned that the investment process was started by the developer who, in order to achieve maximum profits, invested in dense buildings in the area provided for single-family housing.

This fact indicates that it is necessary to harmonize the provisions of law in Polish legislation in such a way that the law is not interpreted, and was unambiguous and includes similar cases.

\section{Acknowledgement}

Publication supported by the Polish Ministry of Science and Higher Education as a part of the program of activities disseminating science from the project „Organization of the First International Science Conference - Ecological and Environmental Engineering”, 26-29 June 2018, Kraków.

This work was carried out within the statutory studies of the AGH University of Science and Technology, Faculty of Mining Surveying and Environmental Engineering, Department of Geomatics No. 11.11.150.006.

\section{References}

1. Hanus, P., Jasinska, E., \& Preweda, E. Analysis of the accuracy of determining the coordinates property borders. The 9th International Conference Environmental Engineering. Vilnius, Lithuania (2014)

2. Hanus, P., Pęska-Siwik, A., \& Szewczyk, R. Computers and Electronics in Agriculture, 144, p. 915. (2018).

3. Jasińska, E. Real Estate Due Diligence On the Example of the Polish Market. 14th SGEM GeoConference on Informatics, Geoinformatics and Remote Sensing 2. SGEM2014. Conference Proceedings, June 19-25,2014, Vol. 2, Bulgaria (2014)

4. Jasińska E. The Adjacency Levy As A Matter Of Regional Policy And Its Efficiency Based On Selected Municipalities. 16th International Multidisciplinary Scientific GeoConference SGEM. SGEM2016 Conference Proceedings, June 28 - July 6, 2016, Book 2 Vol. 2, pp, 601-608 (2016).

5. Jasińska E. 2017. Land use efficiency on example of the transformation of rural properties. The 10th International Conference Environmental Engineering. Vilnius, Lithuania, (2017).

6. Miejscowy plan zagospodarowania przestrzennego na obszarze gminy Zielonki w granicach administracyjnych miejscowości Bibice. Biuletyn Informacji Publicznej Województwa Małopolskiego

7. Uchwała w sprawie Parku Krajobrazowego „Dolinki Krakowskie". Dziennik Urzędowy Województwa Małopolskiego $\mathrm{Nr} 583$, poz. 6624

8. Ustawa $\mathrm{z}$ dnia 30 sierpnia 2002 r. Prawo o postępowaniu przed sądami administracyjnymi (Dz. U. z 2016 r. poz. 718 z późn. zm.)

9. Wyrok Wojewódzkiego Sądu Administracyjnego w Krakowie, Sygn. akt II SA/Kr 686/17 